\title{
The changes of chemical quality of ginger during postharvest storage at chilling temperature
}

\author{
'Shukor, N.I.A., ${ }^{1 *}$ Misran, A., ${ }^{1}$ Ahmad, S.H., ${ }^{1}$ Xue, Y.T., ${ }^{1}$ Mahmud, T.M.M. and ${ }^{2}$ Saari, N. \\ ${ }^{I}$ Department of Crop Science, Faculty of Agriculture, Universiti Putra Malaysia, 43400 UPM Serdang, \\ Selangor, Malaysia \\ ${ }^{2}$ Department of Food Science, Faculty of Food Science and Technology, Universiti Putra Malaysia, 43400 \\ UPM Serdang, Selangor, Malaysia
}

\begin{abstract}
Article history:
Received: 16 March 2020

Received in revised form: 27 April 2020

Accepted: 2 May 2020

Available Online: 12 June 2020
\end{abstract}

Keywords:

Ginger,

Rhizome,

Chilling injury,

Postharvest quality,

Storage

DOI:

https://doi.org/10.26656/fr.2017.4(5).109

\section{Introduction}

Botanically, ginger is known as Zingiber officinale, Zingiberaceae family, a perennial herb that is grown as an annual crop. The thick tuberous rhizome is pale yellow, aromatic with pungent taste (Gupta and Sharma, 2014). Ginger consumption as medicinal herbs has been practised since ancient time in treating various illnesses such as nausea, menstruation disorder, inflammation, cough and cold, food poisoning, epilepsy, and even cancer (Shukla and Singh, 2007). The ability of ginger to reduce the symptoms of those illnesses is related to the therapeutic properties including antimicrobial, antioxidant due to the presence of gingerol and shogaol and its derivatives (Kumar et al., 2011).

In 2016, total production of ginger in Malaysia was recorded to be 13.4 metric tonnes and Pahang produced the highest followed by Selangor, Kelantan, Pulau Pinang, Kedah and Johor. Specifically, Bentong is the district with the highest production of ginger in Pahang which has reached to $7,382.399 \mathrm{~kg}$ in 2016 which is equivalent to RM 64 million of profits (DOA, 2016). However, the high local demand for ginger rhizomes leads to insufficient supply for the local consumers. This has initiated an importation of ginger from China, Thailand and Indonesia to Malaysia. During transportation, the imported rhizomes are stored under refrigeration at low temperatures around $\pm 1{ }^{\circ} \mathrm{C}$ and deposited to a local wholesale market and stored in a cold room under the same condition, causing the rhizomes to manifest its symptoms as translucency and shrivelling when returned to ambient temperature. Eventually, reducing its physical and chemical quality such as the colour, sweetness, acidity, phytochemical contents, antioxidant and enzyme activities. The deteriorating effects have shown that ginger rhizomes were intolerance to chilling temperatures.

Malaysian ginger rhizomes are highly in demand for 
domestic and international consumers especially Bentong ginger. This is supported by recent statistics showing that importation of ginger worth RM 90.6 million in 2017 as compared to exportation only for RM 1.49 million indicating the inadequate supply to meet the local demand (FAMA, 2017). Moreover, the low production of ginger has limited the total capacity of ginger exportation due to insufficient land resources and unsuitable type of soil for the cultivation of ginger. In addition, the infection of soil borne diseases such as fusarium and bacteria wilt causing wet rot on ginger rhizomes also leads to low ginger production (Yasser and Mohamad, 2012).

Storing horticultural produces under lower temperature has been practised since ancient time as a method for preservation as it reduces the overall metabolic rate such as respiration and ethylene production (Wills et al., 2007). Nevertheless, improper management of storage temperature of any produce will lead to disruptions of metabolic and physiological processes in plants thus reducing the postharvest quality of the produce. Moreover, ginger is a tropical produce which is prone to chilling injury when stored at a temperature lower than $15^{\circ} \mathrm{C}$. By storing the rhizomes under this temperature may develop physiological breakdown as it alters the physical properties of cell membranes. This will lead in reduction of the membrane elasticity, decreasing their compliance and preventing lipid inclusion in their composition, lower lipid fluidity, thereby reducing the activity of several membrane-bound enzymes, including $\mathrm{H}^{+}$-ATPase, increase the lateral diffusion of phospholipids, sterols and proteins in the plasma membrane (Kasamo et al., 2000). Chilling injury may be affected by environmental, cultural and or genetically which alter their response to storage temperature (Lukatkin et al., 2012).

Local ginger especially Bentong ginger is high in quality as compared to imported ginger from Indonesia, Thailand, China, Taiwan and the United States. It is highly demanded in Hong Kong and Britain market. Its pungency and the level of heat that gives sensation to the taste bud has attracted attention, not from the local consumers but also worldwide. Therefore, Bentong ginger was chosen in this experiment in determining the optimum storage temperatures and storage durations on the physico-chemical qualities of rhizomes. The ginger rhizomes which were collected from Bentong were stored at 5, 15 and $25^{\circ} \mathrm{C}$ and were kept for $0,8,16$ and 24 days.

\section{Materials and methods}

\subsection{Plant material}

The propagation of rhizomes takes place by portions of mature rhizomes of 12 months known as seed rhizomes. Bentong ginger is cultivated on the terraced hill on a cliff with planting distance is $0.25 \mathrm{~m} \times 0.25 \mathrm{~m}$.

\subsection{Preparation of samples}

Fresh 'Bentong' ginger rhizomes at 9-10 months after planting were supplied from a fresh market in Bentong. The rhizomes were cleaned, wrapped in polyethylene plastic and packed into a box with the dimension of $24 \times 15 \times 30 \mathrm{~cm}$. The fresh and cleaned ginger rhizomes were stored at three storage temperatures $\left(5,15\right.$ and $\left.25^{\circ} \mathrm{C}\right)$ for four storage durations $(0,8,16$ and 24 days). Then, the ginger rhizomes were squeezed for its juice by using a juicer (Hurom HU 100, Korea). The juice was then filtered through Whatman No 1 filter paper. The filtered juice was used to determine for total phenolic content (TPC), total flavonoid content (TFC), identification of 6-gingerol and 6-shogoal and DPPH radical scavenging activity during day 0 and after storage at day 8,16 , and 24.

\subsection{Total phenolic contents}

The TPC was determined using Folin-Ciocalteu reagents (Policegoudra and Aradhya, 2007) with slight modification. An aliquot $(0.1 \mathrm{~mL})$ of ginger juice was added to $2 \mathrm{~mL}$ of $2 \%$ sodium carbonate $\left(\mathrm{Na}_{2} \mathrm{CO}_{3}\right)$ and incubated for 3 mins. Then, $0.1 \mathrm{~mL}$ of $50 \%$ FolinCiocalteu reagent were added and incubated for $30 \mathrm{~min}$ at room temperature. Absorbance was measured at 750 nm using a Multiskan GO microplate spectrophotometer (Thermo Fisher Scientific 1510, Waltham, MA USA). Amounts of TPC was calculated using the gallic acid calibration curve. The results were expressed as gallic acid equivalents (GAE) $\mathrm{g} \mathrm{kg}^{-1}$ of fresh weight (FW).

\subsection{Total flavonoid contents}

TFC was measured by the aluminium chloride colourimetric assay according to Singh et al. (2012). An aliquot $(1 \mathrm{~mL})$ of extracts or standard solutions of rutin $\left(0.05,0.1,0.15,0.2\right.$ and $\left.0.25 \mathrm{~g} \mathrm{~L}^{-1}\right)$ were added to $10 \mathrm{~mL}$ volumetric flask containing $4 \mathrm{~mL}$ of distilled water. First, $0.30 \mathrm{~mL}$ of $5 \%$ sodium nitrate $\left(\mathrm{NaNO}_{3}\right)$ were added into $0.2 \mathrm{~mL}$ of the ginger juice. Then, $0.3 \mathrm{~mL} 10 \%$ aluminium chloride $\left(\mathrm{AlCl}_{3}\right)$ was added after five min. A volume of $2 \mathrm{~mL}$ of $1 \mathrm{M}$ sodium hydroxide $(\mathrm{NaOH})$ was added after 6 mins and the samples were measured against the blank at $510 \mathrm{~nm}$ using a Multiskan GO microplate spectrophotometer (Thermo Fisher Scientific 1510, Waltham, MA, USA). The total flavonoid content was expressed as rutin equivalents (RE) $\mathrm{g} \mathrm{kg}^{-1}$ of fresh 
weight (FW).

\subsection{High performance liquid chromatography}

\subsubsection{Sample preparation}

An aliquot $(1 \mathrm{~mL})$ of ginger juice was membrane filtered through a $0.20 \mathrm{~mm}$ syringe filter (Titan 3, Thermo Scientific), and $10 \mathrm{~mL}$ of the filtrate was subjected to HPLC analysis.

\subsubsection{Standard solution preparation}

The stock solution of $1 \mathrm{gL}^{-1} \mathrm{ppm}$ of 6-gingerol and 6 -shogaol (Chengdu Biopurify Phytochemicals Ltd., China) were prepared in HPLC grade methanol. The stock solution was then serially diluted into $0.05-0.5 \mathrm{gL}$ ${ }^{-1}$ of working solutions for the calibration curves at five concentration levels and were filtered through $0.20 \mathrm{~mm}$ syringe filter (Titan 3, Thermo Scientific). A volume of $10 \mathrm{~mL}$ of standard solutions was injected into HPLC system. The calibration curves were established by the peak areas and concentrations of working solutions.

\subsubsection{Chromatographic separation parameters}

The HPLC system consisted of Agilent 1200 Series equipped with a diode array detector (DAD). The filtered standard and extract solution were injected into a reversed phase Phenomenex Luna C18 (2) 100A (250 $\mathrm{mm} \times 4.6 \mathrm{~mm}, 5 \mathrm{~mm}$ ) with a guard column (Phenomenex C18; 4 x $3.0 \mathrm{~mm}$ i.d, Phenominex Inc., USA). The method was developed by using acetonitrile (A) and deionised water (B) as the mobile phase. The gradient elution is optimized as $95 \%$ water ( 0 to $7 \mathrm{mins}$ ) and followed by $35 \%$ water $(8-10 \mathrm{~min})$. The flow rate was set at $1.0 \mathrm{~mL} / \mathrm{min}$ and the scanning between $200 \mathrm{~nm}$ and 400 $\mathrm{nm}$ was performed. The column temperature was set to $40^{\circ} \mathrm{C}$. The injection volume was $10 \mathrm{~mL}$. Identification of 6-gingerol and 6-shogaol was based on the comparison of the retention times of unknown peaks to those of reference standards while quantification of each compound was carried out by comparison of the area of peaks recorded with calibration curve of standards. The results were expressed in $\mathrm{g} \mathrm{kg}^{-1}$ of fresh weight $(\mathrm{FW})$.

\subsection{1,1- diphenyl picrylhydrazyl (DPPH) free radical scavenging activity}

The antioxidant activity of the ginger juice was determined using 1, 1-diphenyl-2-picrylhydrazyl (DPPH) radical base on the electron transfer reaction between DPPH reagent and the plant extracts. First, $0.4 \mathrm{~mL}$ of ethanol was added into $100 \mu \mathrm{L}$ of ginger juice. Then, 1 $\mathrm{mL}$ of $0.1 \mathrm{mM}$ DPPH was added into the samples and incubated at $37^{\circ} \mathrm{C}$ for an hour. The absorbance value was measured by a Multiskan GO microplate spectrophotometer (Thermo Fisher Scientific 1510,
Waltham, MA, USA) at $517 \mathrm{~nm}$. Percent of inhibition of DPPH was calculated by ((abs control - abs sample) / abs control) x 100 (Maizura et al., 2011).

\subsection{Experimental design and statistical analysis}

The experiment was laid out as randomized completely block design (RCBD), analysed as a two-way factorial comparison of storage temperature $\left(5,15,15^{\circ} \mathrm{C}\right)$ versus storage durations $(0,8,16$ and 24 days $)$ with four replications. Data were subjected to analysis of variance (ANOVA) using the procedure of the general linear model (PROC GLM). Main effects and interactions between two factors were included in the model. Multiple regressions analysis (PROC REG) with two variables was used to determine the effects on postharvest qualities. Means comparison were separated by Tukey's honestly significant difference (HSD) test at $P<0.05$.

\section{Result and discussion}

\subsection{Total phenolic contents and total flavonoid contents}

Total phenolic and flavonoid contents were determined as their role in the prevention of diseases and various biological activities (Rahmani et al., 2014) The TPC was expressed as milligram of gallic acid per $100 \mathrm{~g}$ of fresh weight of ginger. Storage duration was further partitioned resulting in significant cubic orthogonal polynomial (Figure 1). The TPC of the juice of the rhizome treated at 5,15 and $25^{\circ} \mathrm{C}$ for $0,8,16$ and 24 days ranged from $23.0-48.98,22.12-52.2$ and $25.12-$ $42.4 \mathrm{mg} \mathrm{GA} / 100 \mathrm{~g} \mathrm{FW}$, respectively. Figure 1 showed a significant cubic trend when ginger rhizomes were stored throughout $24 \mathrm{~d}$ of storage durations at $5^{\circ} \mathrm{C}$. At $5^{\circ} \mathrm{C}$, TPC dropped and increased significantly from initial to 8 $\mathrm{d}$ of storage durations. The phenolic contents were then continued rising significantly and rapidly by $100 \%$ when reaching $16 \mathrm{~d}$ of storage durations, the TPC of rhizomes were seen to decline again by $52 \%$ at the end of storage durations. The similar fluctuation in the changes of TPC was also observed when the rhizomes were stored at 15 and $25^{\circ} \mathrm{C}$. The amount of total phenolics of the rhizomes at $15^{\circ} \mathrm{C}$ were significantly $7 \%$ higher as compared to storage at $5^{\circ} \mathrm{C}$ and $18 \%$ higher than storage at $25^{\circ} \mathrm{C}$ during storage at day-16. Furthermore, on day-24, stored rhizomes at $5^{\circ} \mathrm{C}$ recorded the lowest decline in TPC than stored rhizomes at 15 and $25^{\circ} \mathrm{C}$ by $13 \%$ and $21 \%$, respectively.

Previous research by Ghasemzadeh et al. (2016) reported that Bentong ginger rhizomes contained a significantly higher content of TPC when refrigerated at $5^{\circ} \mathrm{C}$ than storage at $15^{\circ} \mathrm{C}$ after four months of storage durations. This amount showed a significant reduction from the initial contents of the total phenolic by $27 \%$ and 
$55 \%$ after months of storage at 5 and $15^{\circ} \mathrm{C}$, respectively.

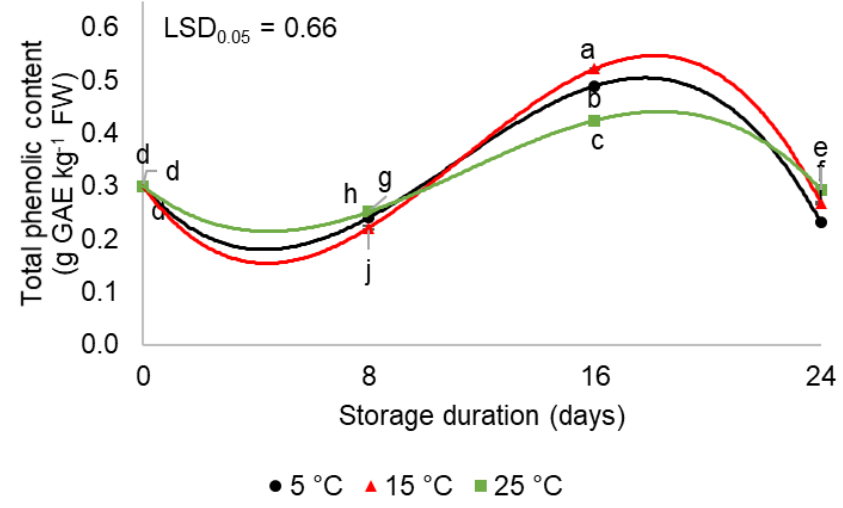

Figure 1. The relationship between total phenolic contents and storage duration $(0,8,16$ and 24 days) at different storage temperatures of ginger $\left(5,15\right.$ and $\left.25^{\circ} \mathrm{C}\right)$. $\mathrm{Y}(5)=30.04-$ $6.09 \mathrm{x}+0.88 \mathrm{x}^{2}-0.026 \mathrm{x}^{3} ; \mathrm{R}^{2}=0.99, \mathrm{Y}(15)=30.04-7.26 \mathrm{x}+$ $1.02 \mathrm{x}^{2}-0.03 \mathrm{x}^{3} ; \mathrm{R}^{2}=0.99, \mathrm{Y}(25)=30.04-4.20 \mathrm{x}+0.58 \mathrm{x}^{2}-$ $0.017 \mathrm{x}^{3} ; \mathrm{R}^{2}=0.99$. Means with the different letters are significantly different at $\mathrm{P}=0.05$. Bars indicate the standard error $(n=4)$.

The most abundant phenolic compound present in ginger rhizomes is gallic acid (Ghasemzadeh et al., 2016). Other phenolics that are distributed in the rhizomes are ferulic acid, tannic acid, cinnamic acid and syringic acid. These compounds were found to reduce its concentration as storage temperatures increased with prolonged storage durations (Ghasemzadeh et al., 2016).

The increasing of TPC content could be due to reaction between phenolic compounds and PPO thus has isomerized parts of the phenolic compounds (Altunkaya and Gökmen, 2009) when the plant is damaged due to storage and inappropriate storage temperature. The rates and cellular sites of ROS production during temperature stress could play a central role in stress perception and protection. As phenolic compound being strong reducing power, the compounds could scavenge the ROS and neutralize it (Suzuki and Mittler, 2006).

The decrease in soluble phenolics was observed toward the end of storage may be due to the breakdown of these cellular structures (Toor and Savage, 2006) leading to oxidation of total phenolic (Cocci et al., 2006). It is assumed that freezing temperatures with disruption of cell membranes may trigger the release of oxidative and hydrolytic enzymes that would destroy the antioxidants (Mohammadian et al., 2011). A similar observation was reported by Hernanz et al., 2009 on the reduction of phenolic contents in red wine after being stored after 12 months. Recent experimental evidence indicated that storage conditions affect the content of phenols to a great extent since they can undergo hydrolysis, oxidation and complexation (Cheynier and Fulcrand, 2003). The reduction in TPC could also be explained by the conversion between free and bound phenolic substances (Ferrante and Maggiore, 2007).

\subsection{Total flavonoid contents}

The changes of flavonoid contents as one of the active ingredients in ginger rhizomes were evaluated and was expressed as g rutin per $\mathrm{kg}$ of rhizome fresh weight.

Regression analysis was further carried out and to partition storage duration into cubic orthogonal polynomial contrasts (Figure 2). Initially, TFC was 0.31 $\mathrm{g}$ RU $\mathrm{kg}^{-1}$ of rhizome fresh weight. The flavonoid contents displayed significant cubic trend when ginger rhizomes were chilled under $5^{\circ} \mathrm{C}$ during 24 days of storage. The TFC was drastically and significantly increasing until day 16 of storage and continue to decrease significantly 8 days after that. A cubic trend was also shown throughout storage at $15^{\circ} \mathrm{C}$. The TFC, however, dropped significantly on $24^{\text {th }}$ day of storage by $88 \%$. At ambient condition $\left(25^{\circ} \mathrm{C}\right)$, the TFC also resulted in similar cubic trend. The TFC of rhizomes was increased significantly but slightly after 8 days of storage and was further decreased until day 24 of storage duration. By end of storage d, stored rhizomes at $15^{\circ} \mathrm{C}$ resulted in the lowest TFC followed by storage at 25 and $5^{\circ} \mathrm{C}$.

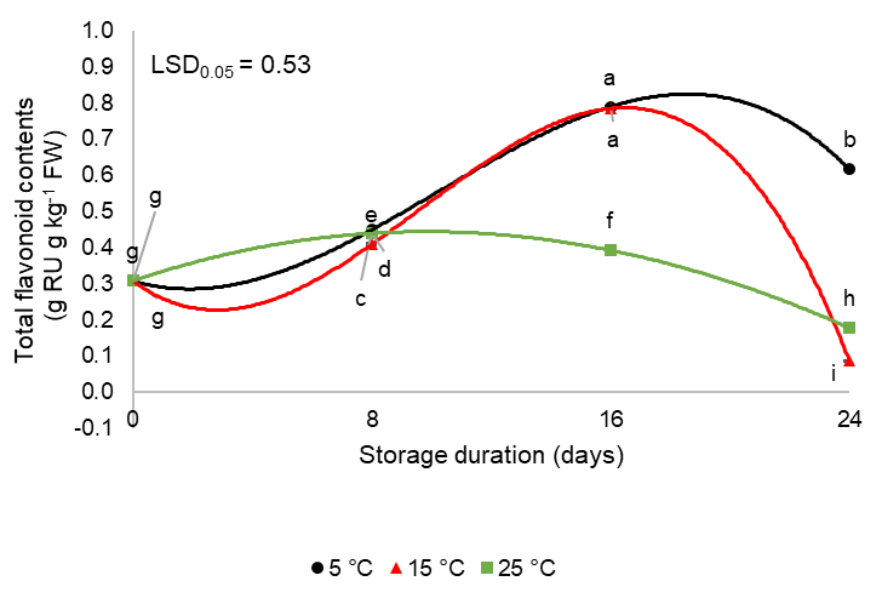

Figure 2. The relationship between total flavonoid contents and storage duration $(0,8,16$ and 24 days) at different storage temperatures $\left(5,15\right.$ and $\left.25^{\circ} \mathrm{C}\right)$ of ginger. $\mathrm{Y}(5)=30.78-2.44 \mathrm{x}$ $+0.71 x^{2}-0.023 x^{3} ; R^{2}=0.99, Y(15)=30.78-6.08 x+1.26 x^{2}$ $-0.04 \mathrm{x}^{3} ; \mathrm{R}^{2}=0.99$ and $\mathrm{Y}(25)=30.78+2.81 \mathrm{x}-0.15 \mathrm{x}^{2}+$ $0.00034 \mathrm{x}^{3} ; \mathrm{R}^{2}=0.99$. Means with the different letters are significantly different at $\mathrm{P}=0.05$. Bars indicate the standard error $(n=4)$.

The common flavonoids found in ginger were quercetin, apigenin, luteolin, myricetin (Ghasemzadeh and Ghasemzadeh, 2011). Other flavonoids that were also found are kaempferol diglycoside, rutin, kaempferol rhamnoside xyloside, diacetylafzelin, pentahydroxyflavone, hemslyanoside, galangin (Ji Soo et 
al., 2015).

The flavonoid contents at low temperatures of 5 and $15^{\circ} \mathrm{C}$ showed a similar pattern of accumulation. The finding was agreed with a study on cassava root showed an increase of flavonoid contents after 3 days of storage at room temperature and followed by a significant decline. Particularly, an accumulation of scopoletin was observed after 8 days of storage (Uarotta and Maraschin, 2015).

Flavonoids are synthesized by the general phenylpropanoid pathway in plants (Winkel-Shirley, 2001). The production for pigmentation of flower and fruit, to regulate polar transport of the phytohormone auxin. Due to the chemical compounds, plants have developed defend mechanism in response to environmental stress such as biotic and abiotic stress (Nakabayashi et al., 2014). Generally, the increase of TFC has been observed during low temperature (Becker et al., 2015) due to abundance of the enzyme that catalyses the biosynthesis of flavonoids and the expression of flavonoid biosynthesis genes in many plant species (Crifò et al., 2011). The production of enzymes such as 2-oxoglutarate-dependent dioxygenase, cytochrome P450, and short-chain dehydrogenase/ reductase that involved in the catalysation in flavonoids biosynthesis resulted in the production of flavonoid contents (Yonekura-Sakakibara et al., 2019).

Improper storage temperature is a causative agent of oxidative stress that trigger the production of reactive oxygen species (ROS) (Wismer, 2003). The ROS has caused damage in cellular components such as DNA, lipids, proteins, and sugars. Therefore, to curb the deteriorations, the ROS homeostasis and the flavonoids and phenolics have come into actions. Plant homeostasis occurs when the accumulation of ROS, antioxidant enzymes' function and low molecular antioxidants come in balance To combat the ROS, the ROS-scavenging mechanism involve enzymes and antioxidant molecules play its role in scavenging the ROS thus neutralising the free radicals (Trchounian et al., 2016) by donating a hydrogen atom thus inactivated the ROS (Treml and Smejkal, 2016). Once the hydrogen atom has been withdrawn from the flavonoid molecules, it would become phenoxyl radical and react with other free radical to produce a stable quinone (Prochazkova et al., 2011) which resulted in the decline of flavonoids. Uarotta and Maraschin (2015) suggested that the increase in flavonoid contents acting as non-enzymatic.

\subsection{Identification and quantification of 6-gingerol and 6- shogaol}

The main active ingredients contained in ginger rhizomes which were 6-gingerol and 6-shogaols were identified and quantified by using HPLC analysis. A significant interaction between storage temperature $(5$, 15 , and $\left.25^{\circ} \mathrm{C}\right)$ and storage duration $(0,8,16$, and 24 days) on 6-gingerol and 6-shogoal content which was expressed as milligram per $100 \mathrm{~g}$ of fresh weight of ginger.

From Figure 3(A), quantification of 6-gingerol in ginger rhizomes juice gave a range from 0.35 to $0.66 \mathrm{~g}$ $\mathrm{kg}^{-1}$ of fresh weight (FW). Partition regression has regressed storage durations into significant cubic trend during rhizome storage at $5^{\circ} \mathrm{C}$. Initially, the 6-gingerol contained $0.35 \mathrm{~g} \mathrm{~kg}^{-1} \mathrm{FW}$. As storage duration begins, the content started to increase significantly after refrigerated at $5^{\circ} \mathrm{C}$ for 8 days. The amount of 6-gingerol sharply increased significantly towards day 16 with a total of increment of $112 \%$. However, the amount dropped significantly by $42 \%$ at the end of the storage duration. Rhizomes that were kept at $15^{\circ} \mathrm{C}$ also portrayed a similar cubic trend. But, the increment of 6-gingerol content from initial to $16 \mathrm{~d}$ of storage was lower by $8.5 \%$ than stored rhizome at $5^{\circ} \mathrm{C}$. Similarly, at ambient condition $\left(25^{\circ} \mathrm{C}\right)$, the changes of 6-gingerol showed a cubic trend. Storage of rhizome at $25^{\circ} \mathrm{C}$ showed a gradual and significant rise from day 0 until day 16 of storage. At day 16, the increment was observed to be the lowest as compared to storage at 5 and $15^{\circ} \mathrm{C}$. 6-gingerol was then continuing to decline slowly on the $24^{\text {th }}$ day of storage duration.

Similar trends of changes in 6-shogaol content were shown (Figure 3 (B)). The content of 6-shogoal was identified in the range of 0.0152 to $0.031 \mathrm{~g} \mathrm{~kg}^{-1}$ of fresh weight. A cubic trend was shown during storage of rhizomes at $5^{\circ} \mathrm{C}$. Initially, the amount of 6-shogaol was quantified to be $0.0152 \mathrm{~g} \mathrm{~kg}^{-1} \mathrm{FW}$. The content increased progressively until day 16 of storage by $103 \%$ and dropped sharply by $37 \%$ at the end of storage day. Storage of rhizome at $15^{\circ} \mathrm{C}$ was observed to be in similar and significant cubic trend as in $5^{\circ} \mathrm{C}$ of storage for 16 days by $93 \%$. However, the 6-shogaol was slightly and significantly reduced by $5 \%$ at day 24 of storage. Meanwhile, at $25^{\circ} \mathrm{C}$, 6-shogaol content increased gradually until the end of storage durations at day 24 . This indicated that the amount of 6-shogaol could be maintained throughout 24 days of storage durations.

Eun-Jeong et al. (2012) reported that the total gingerol content that was refrigerated at $10^{\circ} \mathrm{C}$ showed decreasing trends with an increase in storage time. While at room temperature, the total gingerol content did not change for up to 10 days of storage. This was in accordance with a report which stated that 6-shogaol, a dehydrated form of 6-gingerol, was a minor component 
in ginger and has recently been reported to have more potent bioactivity than 6-gingerol (Ok and Woo-Sik, 2012). According to Rantawaty (2004) who discovered that gingerol loss was very small during storage at $5^{\circ} \mathrm{C}$ as compared to room temperature at $28^{\circ} \mathrm{C}$ throughout 12 weeks of storage. Zhang et al. (1994) concluded that gingerols in all products degraded gradually with storage.
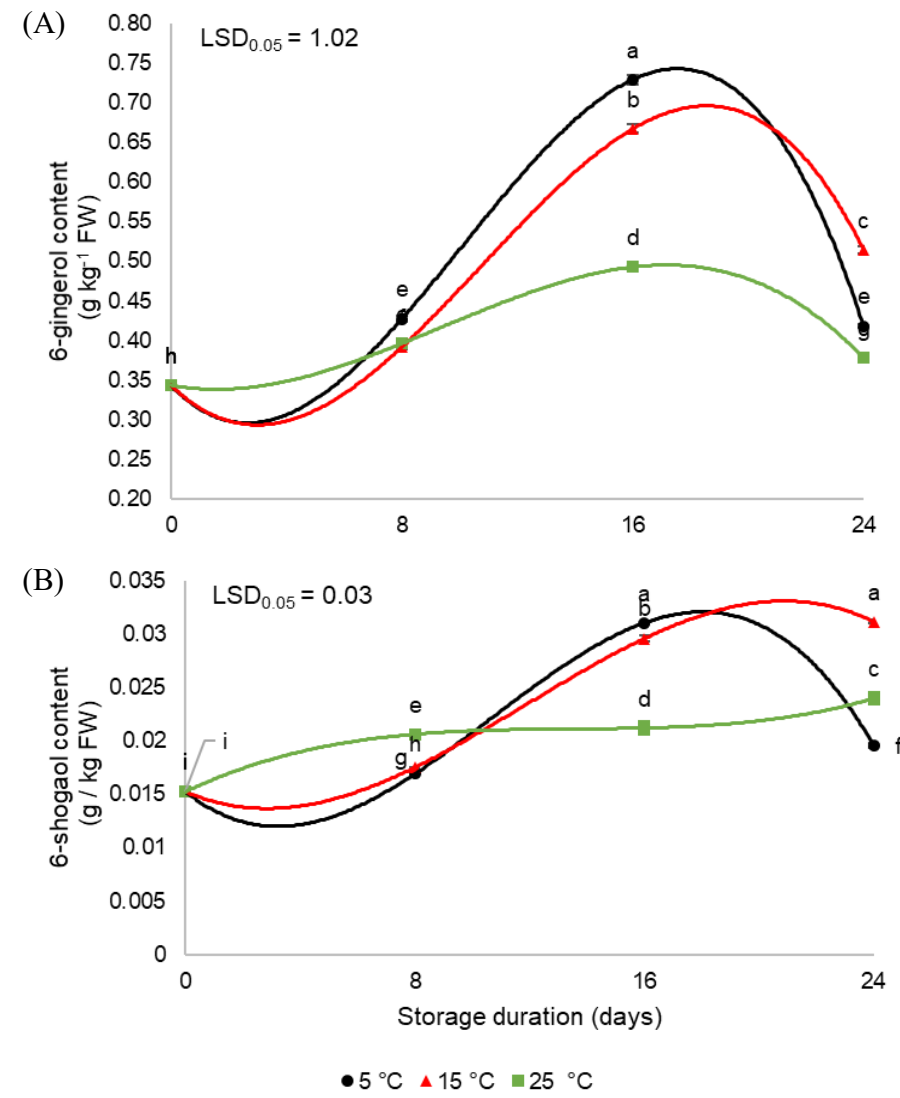

Figure 3. The relationship between 6-gingerol (A) and 6shogaol (B) and storage duration (0, 8, 16 and 24 days) at different storage temperatures $\left(5,15\right.$ and $\left.25^{\circ} \mathrm{C}\right)$ of ginger. (A) $\mathrm{Y}(5)=34.35-3.78 \mathrm{x}+0.82 \mathrm{x}^{2}-0.027 \mathrm{x} 3 ; \mathrm{R}^{2}=0.99, \mathrm{Y}(15)=$ $34.35-3.54 \mathrm{x}+0.68 \mathrm{x}^{2}-0.021 \mathrm{x}^{3} ; \mathrm{R}^{2}=0.99$ and $\mathrm{Y}(25)=$ $34.35-0.68 \mathrm{x}+0.23 \mathrm{x}^{2}+0.0083 \mathrm{x}^{3} ; \mathrm{R}^{2}=0.99$. (B) $\mathrm{Y}(5)=$ $1.52-0.22 \mathrm{x}+0.03 \mathrm{x}^{2}-0.012 \mathrm{x}^{3} ; \mathrm{R}^{2}=0.99, \mathrm{Y}(15)=1.52-$ $0.12 \mathrm{x}+0.023 \mathrm{x}^{2}-0.0007 \mathrm{x}^{3} ; \mathrm{R}^{2}=0.99$ and $\mathrm{Y}(25)=1.52+$ $0.13 \mathrm{x}-0.0092 \mathrm{x}^{2}+0.0002 \mathrm{x}^{3} ; \mathrm{R}^{2}=0.99$. Means with the different letters are significantly different at $\mathrm{P}=0.05$. Bars indicate the standard error $(n=4)$.

6-gingerol is phenolic alkanone compound with the presence of b-hydroxy (Denniff et al., 1981) which contributed to the pungency of ginger rhizome and were believed to exert a variety of remarkable pharmacological and physiological activities (Sanwal et al., 2010). The $\beta$-hydroxyl ketone moiety in 6-gingerol is converted to 6-shagoal via dehydration and was deprotonated into alkenes thus producing conjugation of the $\alpha, \beta$-unsaturated ketone skeleton in the chemical structure under high temperature or acidic condition (Kou et al. 2018) and prolonged storage (Wohlmuth, 2008). This compound is present in significantly lower quantities since they represent biogenetically only sideproducts of gingerols (Jiang et al., 2005).

It is clear that the conversion of gingerol to shogaol is affected by temperature, but it also depends on the impact of heat type, sample type, and time of heat exposure (Yhung Jung et al., 2018). In this experiment, the temperatures of storage that were applied were 5, 15 and $25^{\circ} \mathrm{C}$ which does not involve heating of the samples. Storage of rhizomes under 5,15 and $25^{\circ} \mathrm{C}$ was not possible for any conversion to occur. Initially, 6-gingerol and 6-shogaols contents were constituted to be 0.35 and $0.015 \mathrm{~g} \mathrm{~kg}^{-1}$ of fresh weight. Gopi et al. (2015) stated that application of heat at 60 and $70^{\circ} \mathrm{C}$ on ginger rhizome resulted in a ratio of 6-gingerols to 6-shagaols to have a value of 1 as compared to $22: 1$ as resulted from this analysis. Extreme temperature reaching 100 to $120^{\circ}$ $\mathrm{C}$ showed a significant conversion of these active compounds, where a rapid degradation of gingerol to form shogaol was observed. Therefore, it could be suggested that the changes of these compounds could be related to oxidative stress. The highest increasing trend of 6-gingerol was noted at $5^{\circ} \mathrm{C}$, followed by $15^{\circ} \mathrm{C}$ and $25^{\circ} \mathrm{C}$. As 6-gingerol and 6-shogaol are categorized under phenolics, these compounds may be responsible in scavenging free radicals produced as a result on improper storage management. The chilling temperature could trigger the transcript, protein, and activity of different ROS-scavenging enzymes (Sato et al., 2001). Low-temperature stress was also shown to induce buildup of hydrogen peroxide in cells. The disruption of mitochondrial function that reduces the expression of cold-responsive genes which eventually lead to the accumulation of ROS. So, the secondary metabolites such as 6-gingerol and 6-shogaol play a role in scavenging free radicals. With the presence of the hydroxyl group and the short carbon chain in its chemical structure, 6-gingerol was reported to possess stronger antioxidant activity as compared to other derivatives of gingerols such as 8 and 10-gingerols. However, for 6-shogaol, despite being the minor contribution in ginger rhizomes, it was reported that 6shogaols exhibited the greatest antioxidant capacity among other gingerols and shogaols. The high potency of this compound is attributed by the $\alpha, \beta$-unsaturated ketone moieties in its structure (Guo et al., 2014). It was observed that at room temperature, the content of 6gingerol and 6-shogaol was at gradual increased indicating that this temperature is suitable in maintaining the active ingredients.

\subsection{1,1-diphenyl-1-picrylhydrazyl (DPPH) radical scavenging capacity assays}

The scavenging of DPPH was expressed in percentage of DPPH inhibition by the antioxidant 
compound from the ginger juice.

Figure 4 shows the relationship between the percentage of DPPH inhibition and storage duration $(0$, 8,16 and 24 days) at different storage temperatures of ginger $\left(5,15\right.$ and $\left.25^{\circ} \mathrm{C}\right)$. Stored rhizome at $5^{\circ} \mathrm{C}$ showed significant cubic decreased throughout storage durations. The inhibition of DPPH decreased significantly by $22.4 \%$ at the end of storage durations. In addition, storage at $15^{\circ} \mathrm{C}$ also resulted in a significant cubic relationship after 24 days of storage. A significant and drastic reduction in percentage inhibition of DPPH was seen during storage of rhizomes at $15^{\circ} \mathrm{C}$ two times higher than those stored at $5^{\circ} \mathrm{C}$. Similar trend was observed during storage at $25^{\circ} \mathrm{C}$ with fluctuation in the changes of percentage. The inhibition of DPPH was significantly dropped by $89 \%$ by 16 days of storage and was continue to increase significantly to $84 \%$ at day 24 of storage.

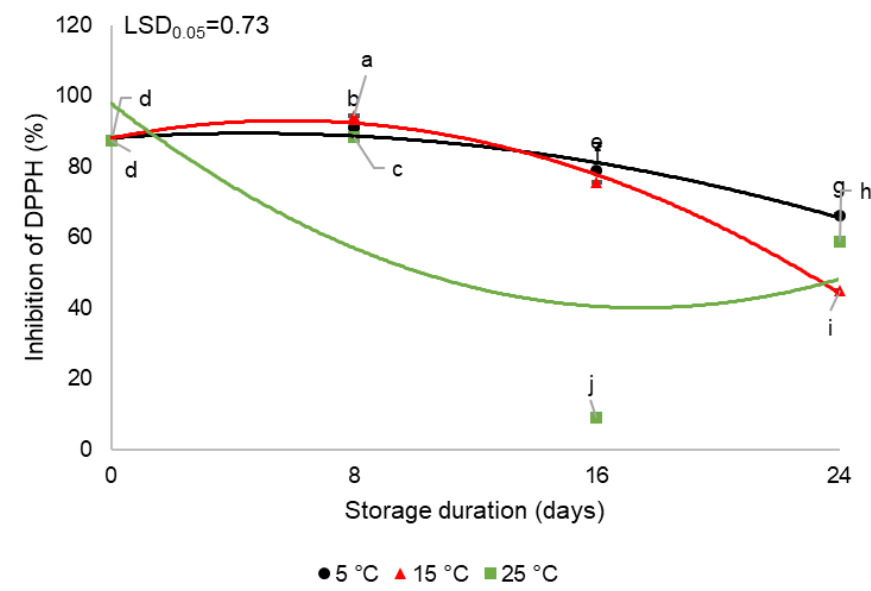

Figure 4. The relationship between percentage of DPPH inhibition and storage duration $(0,8,16$ and 24 days $)$ at different storage temperature of ginger $\left(5,15\right.$ and $\left.25^{\circ} \mathrm{C}\right)$. $\mathrm{Y}$ $(5)=87.4+2.05 x-0.24 x^{2}+0.0049 x^{3} R^{2}=0.99, Y(15)=$ $87.4+3.04 \mathrm{x}-0.31 \mathrm{x}^{2}+0.0044 \mathrm{x}^{3} ; \mathrm{R}^{2}=0.99, \mathrm{Y}(25)=87.40+$ $13.88 \mathrm{x}-2.26 \mathrm{x}^{2}+0.068 \mathrm{x}^{3} ; \mathrm{R}^{2}=0.99$. Means with the different letters are significantly different at $\mathrm{P}=0.05$. Bars indicate the standard error $(n=4)$.

The decreasing trend in the percentage of DPPH inhibition in rhizome stored at $5^{\circ} \mathrm{C}$ was associated with the reduction of antioxidant content in the rhizome to neutralize the DPPH free radical (Candrawinata et al., 2014). A study by Kang and Saltveit (2002a) reported the correlation between higher levels of DPPH activity and the increased chilling tolerance in heat-shocked rice seedling radicles. The chilling-tolerant short radicles showed higher levels of DPPH activity than longer, more chilling sensitive radicles (Kang and Saltveit 2002b). There also appears to be a correlation between DPPH activity in cucumber radicles and vigour difference in chilling sensitivity.

A study on cucumber seedling radicles has revealed that chilling reduced DPPH activity in both high- and low-vigour tissue, and it did not recover after $48 \mathrm{hrs}$ of growth at $25^{\circ} \mathrm{C}$. The level of activity in low-vigour radicles decreased to $58 \pm 3 \%$ of that in high-vigour radicles assayed either immediately after chilling, or after an additional $48 \mathrm{hrs}$ at $25^{\circ} \mathrm{C}$ (Kang and Saltveit, 2002b). Similar findings also supported that there was a significant reduction in the antioxidant activity in the flavedo of Citrus sinensis 'Siavaraz' at $-6^{\circ} \mathrm{C}$ compared with control samples stored at $15^{\circ} \mathrm{C}$ (Mohammadian et al. 2011).

It is also known that the antioxidant activity of phenolic compounds is closely associated with their structures, such as substitutions on the aromatic ring and side-chain structure. The strong antiradical activity of phenolic and flavonoid could be due to the presence of conjugated double bond, which makes the electrons more delocalized (Wagh et al., 2012). Moreover, their accessibility to the radical centre of DPPH・ could also influence the order of antioxidant power.

\section{Conclusion}

From the results, there was a significant interaction on chemical properties when the Bentong ginger rhizomes were treated at storage temperatures of 5, 15 and $25^{\circ} \mathrm{C}$ for $0,8,16$ and 24 days. An execution of orthogonal partition of storage duration has resulted in linear, quadratic or cubic polynomial depending on the measured variables. The phytochemical analysis resulted in similar increments in total phenolic and flavonoid when stored at 5 and $15^{\circ} \mathrm{C}$ up to 16 days of storage durations. The active compound which is the 6-gingerol was identified to be the major component as opposed to 6 -shogaol which present in small quantity. It showed that storage at $25^{\circ} \mathrm{C}$ could retain 6-gingerol and 6-shogaol up to 16 days of storage. For DPPH activities, the antioxidant capacity became weaker especially during storage at $25^{\circ} \mathrm{C}$.

\section{Conflict of interest}

The authors declare no conflict of interest.

\section{Acknowledgments}

The authors are grateful for the financial support by the IPS grant of the University of Putra Malaysia (Grant No. 9483200).

\section{References}

Altunkaya, A. and Gokmen, V. (2009). Effect of various anti-browning agents on phenolic compounds profile of fresh lettuce (L. sativa). Food Chemistry, 117(1), 122-126. 


\section{j.foodchem.2009.03.085}

Becker, C., Klaering, H. P., Kroh, L.W. and Krumbein, A. (2014). Cool-cultivated red leaf lettuce accumulates cyanidin-3-O-(6"-O-malonyl)-glucoside and caffeoylmalic acid. Food Chemistry, 146, 404411. https://doi.org/10.1016/j.foodchem.2013.09.061

Candrawinata, V.I., Golding, J.B., Roach, P.D. and Stathopoulos, C.E. (2014). Total phenolic content and antioxidant activity of apple pomace aqueous extract: Effect of time, temperature and water to pomace ratio. International Food Research Journal, 21(6), 2337-2344.

Cheynier, V. and Fulcrand. H. (2003). Analysis of polymeric proanthocyanidins and complex polyphenols. In Santos Buelga, C. and Williamson, G. (Eds.), Methods in Polyphenol Analysis, p. 284313. Cambridge, United Kingdom: Royal Society of Chemistry.

Cocci, E., Rocculi, P., Romani, S. and, Rosa, M.D. (2006). Changes in nutritional properties of minimally processed apples during storage. Postharvest Biology and Technology, 39(3), 265271.

j.postharvbio.2005.12.001

Crifò, T., Puglisi, I., Petrone, G., Recupero, G.R. and Lo Piero, A.R. (2011). Expression analysis in response to low temperature stress in blood oranges: implication of the flavonoid biosynthetic pathway. Gene, $\quad 476(1-2), 1-9 . \quad$ https://doi.org/10.1016/ j.gene.2011.02.005

Denniff, P., Macleod, I. and Whiting, D.A. (1981) Syntheses of the $( \pm)$-[n]-gingerols (pungent principles of ginger) and related compounds through regioselective aldol condensations: relative pungency assays. Journal of the Chemical Society, Perkin Transactions, 1, 82-87. https:// doi.org/10.1039/P19810000082

Department of Agriculture (DOA). (2016). Herbs and spices statistics. Putrajaya, Malaysia: Department of Agriculture.

Eun-Jeong, C., Kyung-A, L. and Kyung-Hyung, K. (2012). Effect of pre-treatment and storage conditions on the quality characteristics of ginger paste. Preventive Nutrition and Food Science, 17(1), 46-52. https://doi.org/10.3746/pnf.2012.17.1.046

FAMA. (2017). Statistik utama pengeluaran FAMA. Retrieved on 1 March, 2019 from FAMA website: http://www.fama.gov.my. [In Bahasa Malaysia].

Ferrante, A. and Maggiore, T. (2007). Chlorophyll fluorescence measurements to evaluate storage time and temperature of Valeriana leafy vegetables.
Postharvest Biology and Technology, 45(1), 73-80. https://doi.org/10.1016/j.postharvbio.2007.02.003

Ghasemzadeh, A., Ashkani, S., Baghdadi, A., Pazoki, A., Jaafar, H.Z.E. and Rahmat, A. (2016). Improvement in flavonoids and phenolic acids production and pharmaceutical quality of sweet basil (Ocimum basilium L.) by ultraviolet-B irradiation. Molecules, 21(9), 1-15. https://doi.org/10.3390/ molecules21091203

Ghasemzadeh, A. and Ghasemzadeh, N. (2011). Flavonoids and phenolic acids: Role and biochemical activity in plants and human. Journal of Medicinal Plants Research, 5(31), 6697-6703. https://doi.org/10.5897/JMPR11.1404

Gopi, S., Varma, K. and Jude, S. (2015). Study on temperature dependent conversion of active components of ginger. International Journal of Pharma Sciences, 6(1), 1344-1347.

Guo, J., Wu, H., Du, L., Zhang, W. and Yang, J. (2014). Comparative antioxidant properties of some gingerols and shogaols, and the relationship of their contents with the antioxidant potencies of fresh and dried ginger (Zingiber officinale Roscoe). Journal of Agricultural Science and Technology, 16(5), 10631072.

Gupta, S.K. and Sharma, A. (2014). Medicinal properties of Zingiber officinale Roscoe - A Review. Journal of Pharmacy and Biological Sciences, 9(5), 124-129. https://doi.org/10.5897/JMPR11.1404

Hernanz, D., Gallo, V., Recamales, A.F., MeléndezMartínez, A.J., González-Miret, M.L. and Heredia, F. J. (2009). Effect of storage on the phenolic content, volatile composition and colour of white wines from the varieties Zalema and Colombard. Food Chemistry, 113(2), 530-537. https:// doi.org/10.1016/j.foodchem.2008.07.096

Ji Soo, H., Sunmin, L, Hyang Yeon, K. and Choong Hwan, L. (2015). MS-based metabolite profiling of aboveground and root components of Zingiber mioga and officinale. Molecules, 20(9), 1617016185. https://doi.org/10.3390/molecules200916170

Jiang, H., Sólyom, A.M., Timmermann, B.N. and Gang, D.R. (2005). Characterization of gingerol-related compounds in ginger rhizome (Zingiber officinale Rosc.) by high-performance liquid chromatography/ electrospray ionization mass spectrometry. Rapid Communication in Mass Spectrometry, 19(20), 2957 -2964. https://doi.org/10.1002/rcm.2140

Kang, H.M. and Saltveit, M.E. (2002a). Reduced chilling tolerance in elongating cucumber seedling radicles is related to their reduced antioxidant enzyme and DPPH-radical scavenging activity. Physiologia 
Plantarum, 115(2), 244-250. https://doi.org/10.1034/ j.1399-3054.2002.1150210.x

Kang, H.M. and Saltveit, M.E. (2002b). Effect of chilling on antioxidant enzymes and DPPH-radical scavenging activity of high- and low-vigour cucumber seedling radicles. Plant Cell and Environment, 25(10), 1233-1238. https:// doi.org/10.1046/j.1365-3040.2002.00915.x

Kou, X., Ke, Y., Wang, X., Rahman, M.R.T., Xie, Y., Chen, S. and Wang, H. (2018). Simultaneous extraction of hydrophobic and hydrophilic bioactive compounds from ginger (Zingiber officinale Roscoe). Food Chemistry, 257, 223-229. https:// doi.org/10.1016/j.foodchem.2018.02.125

Kumar, G., Kathie, L. and Rao, K.V.B. (2011). A review on pharmacological and phytochemical properties of Zingiber officinale Roscoe (Zingiberaceae), Journal of Pharmacy Research, 4(9), 2963-2966.

Kasamo K., Yamaguchi, M. and Nakamura, Y. (2000). Mechanism of the chilling-induced decrease in proton pumping across the tonoplast of rice cells. Plant and Cell Physiology, 41(7), 840-849. https:// doi.org/10.1093/pcp/pcd002

Lukatkin, A.S., Brazaityte, A., Bobinas, C. and Duchovskis, P. (2012). Chilling injury in chillingsensitive plants: a review. Žemdirbyste = Agriculture, 99(2), 111-124.

Maizura, M., Aminah, A. and Wan Aida, W.M. (2011). Total phenolic content and antioxidant activity of kesum (Polygonum minus), ginger (Zingiber officinale) and turmeric (Curcuma longa) extract. International Food Research Journal, 18, 529-534.

Mohammadian, M.A., Mobrami, Z. and Sajedi, R.H. (2011). Bioactive compounds and antioxidant capacities in the flavedo tissue of two citrus cultivars under low temperature. Brazilian. Journal. Plant Physiology, 23(3), 1677-9452. https:// doi.org/10.1590/S1677-04202011000300004

Nakabayashi, R., Mori, T. and Saito, K. (2014). Alternation of flavonoid accumulation under drought stress in Arabidopsis thaliana. Plant Signal and Behavior, 9(8), 1-3. https://doi.org/10.4161/ psb. 29518

Ok, S. and Woo-Sik, J. (2012). Optimization of extraction conditions for the 6-shogaol-rich extract from ginger (Zingiber officinale Roscoe). Preventive Nutrition and Food Science, 17(2), 166-171. https:// doi.org/10.3746/pnf.2012.17.2.166

Policegoudra, R.S. and Aradhya, S.M. (2007). Biochemical changes and antioxidant activity of mango ginger (Curcuma amada Roxb.) rhizomes during postharvest storage at different temperatures.
Postharvest Biology and Technology, 46(2), 189194.

https://doi.org/10.1016/

j.postharvbio.2007.04.012

Prochazkova, D., Bousova, I. and Wilhelmova, N. (2011). Antioxidant and prooxidant properties of flavonoids. Fitoterapia, 82(4),513-23. https:// doi.org/10.1016/j.fitote.2011.01.018

Rahmani, A.H., Al Shabrmi, F.M. and Aly, S.M. (2014). Active ingredients of ginger as potential candidates in the prevention and treatment of diseases via modulation of biological activities. International Journal of Pathophysiology and Pharmacology, 6 (2), 125-136.

Rantawaty, F. (2004). Improvement of quality and storage stability of ginger (Zingiber officinale Rosc.) drink. Serdang: University of Putra Malaysia, MSc. Thesis.

Sanwal, S.K., Rai, N., Singh, J. and Buragohain, J. (2010). Antioxidant phytochemicals and gingerol content in diploid and tetraploid clones of ginger (Zingiber officinale Roscoe). Scientia Horticulturae, 124(2), 280- 285. https://doi.org/10.1016/ j.scienta.2010.01.003

Sato, Y., Murakami, T., Funatsuki, H., Matsuba, S., Saruyama, H. and Tanida, M. (2001). Heat shockmediated APX gene expression and protection against chilling injury in rice seedlings. Journal of Experimental Botany, 52(354), 145-151. https:// doi.org/10.1093/jexbot/52.354.145

Shukla, Y. and Singh, M. (2007). Cancer preventive properties of ginger: a brief review. Food Chemical and Toxicology, 45(5), 683-690. https:// doi.org/10.1016/j.fct.2006.11.002

Singh, V., Guizani, N., Essa, M.M., Hakkim, F.L. and Rahman, M.S. (2012). Comparative analysis of total phenolics, flavonoid content and antioxidant profile of different date varieties (Phoenix dactylifera L.) from Sultanate of Oman. International Food Research Journal, 9, 1063-1070.

Suzuki, N. and Mittler, R. (2006). Reactive oxygen species and temperature stresses: A delicate balance between signaling and destruction. Physiologia Plantarum, 126(1), 45-51. https://doi.org/10.1111/ j.0031-9317.2005.00582.x

Toor, R.K. and Savage, G.P. (2006). Changes in major antioxidant components of tomatoes during postharvest storage. Food Chemistry, 99(4), 724-727. https://doi.org/10.1016/j.foodchem.2005.08.049

Trchounian A., Petrosyan M. and Sahakyan, N. (2016) Plant cell redox homeostasis and reactive oxygen species. In Gupta, D., Palma J. and Corpas, F. (Eds.), Redox State as a Central Regulator of Plant-Cell 
Stress Responses. p. 25-50. Switzerland: Springer, Cham. https://doi.org/10.1007/978-3-319-44081-1_2

Treml, J. and Smejkal, K. (2016). Flavonoids as potent scavengers of hydroxyl radicals. Comprehensive Reviews in Food Science and Food Safety, 15(4), 720-738. https://doi.org/10.1111/1541-4337.12204

Uarotta, V.G. and Maraschin, M. (2015). Metabolomic, enzymatic, and histochemical analysis of cassava roots during postharvest physiological deterioration. BMC Research Notes, 648. https://doi.org/10.1186/ s13104-015-1580-3

Wagh, S.S., Jain, S.K., Patil, A.V. and VadnereIn, G.P. (2012). Vitro free radical scavenging and antioxidant activity of Cicer arietinum L. (Fabaceae). International Journal of PharmTech Research, 4(1), 343-350.

Wills, R.B.H., McGlasson, W.B., Graham, D. and Joyce, D.C. (2007). Postharvest: An introduction to the physiology and handling of fruit, vegetables and ornamentals. $5^{\text {th }}$ ed. Australia: University of New South Wales Press. https:// doi.org/10.1079/9781845932275.0013

Winkel-Shirley, B. (2001). Flavonoid biosynthesis. A colorful model for genetics, biochemistry, cell biology, and biotechnology. Plant Physiology, 126 (2), 485-493. https://doi.org/10.1104/pp.126.2.485

Wismer, W.V. (2003). Low temperature as a causative agent of oxidative stress in poestharvest crops. In Hodges, D.M. (Ed.) Postharvest oxidative stress in horticultural crops, p. 57. Binghamton: The Haworth Press.

Wohlmuth, H., (2008). Phytochemistry and pharmacology of plants from the ginger family, Zingiberaceae. Australia: Southern Cross University, Lismore, New South Wales, PhD Thesis.

Yasser, S.M. and Mohamad, A.M. (2012). Commercial ginger production using fertigation system. Buletin Teknologi MARDI, 1, 97-105.

Yhung Jung, M., Kyoung Lee, M., Jeong Park, H., Oh, E.B., Young Shin, J., Su Park, J., Young Jung, S., Oh, J.H. and Choi, D.S. (2018). Heat-induced conversion of gingerols to shogaols in ginger as affected by heat type (dry or moist heat), sample type (fresh or dried), temperature and time. Food Science and Biotechnology, 27(3), 687-693. https:// doi.org/10.1007/s10068-017-0301-1

Yonekura-Sakakibara, K., Higashi, Y. and Nakabayashi, R. (2019). The origin and evolution of plant flavonoid metabolism. Frontier in Plant Science, 2019, 943. https://doi.org/10.3389/fpls.2019.00943

Zhang, X., Iwaoka, W.T., Huang, A.S., Nakamoto, S.T. and Wong, R. (1994). Gingerol decreases after processing and storage of ginger. Journal of Food Science, 59(6), 1338-1340. ttps://doi.org/10.1111/ j.1365-2621.1994.tb14710.x 